\title{
TINGKAT KESEJAHTERAAN DAN \\ KETAHANAN PANGAN RUMAHTANGGA NELAYAN MISKIN: Studi Kasus di Kelurahan Marunda Baru, DKI Jakarta dan Desa Tanjung Pasir, Banten
}

\author{
Tajerin, Sastrawidjaja dan Risna Yusuf \\ Balai Besar Riset Sosial Ekonomi Kelautan dan Perikanan \\ Jl. KS. Tubun Petamburan VI Jakarta 10260 \\ Telp. (021) 53650162, Fax. (021)53650159 \\ Diterima 18 Februari 2011 - disetujui 21 Mei 2011
}

\begin{abstract}
ABSTRAK
Tujuan penelitian ini adalah untuk mengetahui hubungan tingkat kesejahteraan dengan ketahanan pangan rumahtangga nelayan miskin di perkotaan (kasus Kelurahan Marunda, Kota Jakarta Utara) dan perdesaan (kasus Desa Tanjung Pasir, Kabupaten Tangerang). Penelitian dilakukan dengan metoda survey dengan menggunakan data primer dan dianalisis berdasarkan pendekatan statistik non-parametrik korelasi Rank-Spearman. Hasil penelitian menunjukkan bahwa terdapat hubungan yang positif dan nyata antara tingkat kesejahteraan dengan ketahanan pangan rumahtangga nelayan miskin di perkotaan maupun perdesaan. Selain itu terdapat hubungan yang positif dan nyata: (1) Antara kesehatan dan gizi dengan pemanfaatan pangan dan akses pangan; (2) Antara kekayaan materi dengan akses pangan dan pemanfaatan pangan; dan (3) Antara pengetahuan dengan ketersediaan pangan, akses pangan dan pemanfaatan pangan. Tampak bahwa aspek pengetahuan merupakan faktor terpenting dalam meningkatkan ketahanan pangan rumahtangga nelayan miskin, di samping faktor kesehatan dan gizi, dan faktor kekayaan materi. Oleh karena itu, kebijakan peningkatan ketahanan pangan pada rumahtangga nelayan miskin dapat diarahkan dengan memberikan perioritas pada peningkatan pengetahuan yang dimiliki rumahtangga nelayan tersebut, dan tentunya dengan meningkatkan aspek pangannya terutama melalui perbaikan jaringan distribusi bahan pangan.
\end{abstract}

Kata Kunci: kemiskinan, kesejahteraan, ketahanan pangan, nelayan

\section{Abstract : Welfare Level and Food Security at Poor Fisher's Household. by: Tajerin, Sastrawidjaja and Risna Yusuf}

The objective of this research is to assess the relationship of welfare level and food security at urban poor fisher household (case study at Village of Marunda - North Jakarta) and rural (Village of Tanjung Pasir-Regency of Tangerang). The research used survey method with primary data and analized by using non-parametric approach with rank-speraman correlation. Result showed that there were positive and significant relationship between welfare level with food security at poor fisher household both of urban and rural. Beside that there was positive and significant relationship: (1) between health and nutrition with using of food and accessibility of food; (2) between wealth with using of food; and (3) between availability of food, accessibility and using of food. In additional, knowledge aspect was the important factor in term of increasing of food security beside health and nutrition factor and wealth factor. Therefore, the policy for increasing of food security for poor fishers household can be focused on not only increasing of knowlegde of fisher but also increasing of accessibility of food especially by recovery of channel material food.

Keywords: poor, welfare, food security, fisher 


\section{PENDAHULUAN}

Kemiskinan merupakan masalah pembangunan yang telah ada sejak dahulu, dan semua negara tidak terkecuali negaranegara maju mengalami hal tersebut. Di kebanyakan negara saat ini menunjukkan ada indikasi gejala kemiskinan yang semakin memburuk (Daryanto dan Hafizrianda, 2010). Menurut catatan World Bank ada 5 miliar penduduk dunia, 1,2 miliar diantaranya tergolong miskin (Siregar et al., 2009a). Karena itu pada Millenium Summit 2000 semua negara-negara anggota PBB telah menyepakati dalam The Millenium Development Goals (MDGs) ditargetkan bahwa pada tahun 2015 kemiskinan dunia dapat diturunkan menjadi 50\% (Yudhoyono dan Harniati, 2004).

$\mathrm{Di}$ Indonesia kemiskinan telah menjadi penyakit kronis masyarakat yang tidak pernah hilang hingga saat kini, termasuk yang terjadi pada wilayah pesisir yang sebagian besar penduduknya berprofesi sebagai nelayan. Data terakhir menunjukkan bahwa sebanyak 32 persen dari 4 juta kepala keluarga nelayan di pesisir perkotaan dan perdesaan hidup dalam kondisi miskin (Satria, 2009). Apabila rata-rata satu keluarga mencapai lima (5) jiwa, maka masyarakat nelayan di pesisir perkotaan dan perdesaan Indonesia adalah sebanyak 20 juta jiwa dengan 6,4 juta jiwa yang miskin.

Namun demikian, diduga tingkat kemiskinan masyarakat nelayan di pesisir perkotaan akan mengalami dinamika yang berbeda dibandingkan perdesaan. Hal ini karena nelayan miskin di perkotaan akan berada dalam kondisi yang relatif lebih tertekan secara ekonomi daripada di perdesaan. Sebagai gambaran, pada tahun 1998 akibat adanya krisis ekonomi, tingkat kemiskinan di Indonesia melonjak tinggi hinga mencapai $120 \%$ bila dibandingkan dengan tahun 1996. Kenaikan paling tinggi terjadi pada kemiskinan perkotaan yang mencapai $144,4 \%$, sedangkan kemiskinan di perdesaan naik sekitar 108,5\% (BPS, 2006).
Perbedaan angka kenaikan kemiskinan antara perkotaan dan perdesaan tersebut diduga berkaitan dengan kekuatan pondasi sistem perekonomian perdesaan yang relatif baik dibandingkan perkotaan.

Baik di perkotaan maupun perdesaan, kemiskinan masyarakat nelayan tersebut perlu mendapatkan upaya-upaya pencegahan dan penanggulangannya secara serius, sehingga masyarakat nelayan tersebut memiliki kemampuan untuk melepaskan diri dari "jerat kemiskinan" (poverty trap). $\mathrm{Hal}$ ini mengingat jerat kemiskinan tersebut telah menyebabkan kesejahteraan dan aksesnya yang rendah terutama bila dikaitkan dengan kemampuannya dalam memenuhi kebutuhan standar hidup dari sektor pangan. Dalam jangka panjang, bila kondisi ini tidak diatasi, akan menurunkan tingkat kesehatan dan produktivitas anggota keluarga/rumahtangga nelayan, dan pada gilirannya akan masuk dalam "jerat kemiskinan" yang lebih dalam (Satria, 2009).

Berkaitan dengan hal tersebut, pemerintah telah melakukan penajaman ulang pembangunan untuk meningkatkan kesejahteraan masyarakat melalui berbagai program, khususnya ekonomi (Aviliani, 2009). Upaya meningkatkan kesejahteraan tersebut juga dilakukannya melalui program ketahanan pangan yang diintegrasikan dengan program besar pencapaian Millenium Development Goals (MDGs), khususnya pengentasan kemiskinan dan kelaparan termasuk bagi lapisan masyarakat terbawah seperti masyarakat nelayan miskin. Hal ini karena ketahanan pangan menunjukkan adanya akses setiap individu untuk memenuhi kebutuhan pangan setiap saat terkait dengan upaya meningkatkan kesejahteraannya (Setiawan, 2010).

Relevan dengan pandangan tersebut, ketahanan pangan bagi rumahtangga nelayan miskin akan menjadi sulit tercapai bila aksesnya terhadap pangan (access to food) dalam kondisi yang rendah, khususnya karena 
alasan dari sisi akses ekonomi (kesejahteraan) seperti pendapatan, kesempatan kerja, dan harga pangan. Bahkan sangat dimungkinkan, nelayan miskin juga mengalami ketidakpastian dalam kecukupan pangan (food sufficiency) dan jaminan pangan (food security) serta keberlanjutan pangan (food sustainability). Hal ini karena secara struktural, nelayan miskin juga mengalami kondisi dalam posisi ketiadaan akses pada pilihan-pilihan dan hak-hak yang seharusnya melekat di bidang sosial, politik, ekonomi, kebudayaan dan lingkungan hidup (Setiawan, 2010).

Untuk itu, telah dilakukan penelitian dengan tujuan untuk menganalisis keragaan tingkat kesejahteraan dan ketahanan pangan rumahtangga nelayan miskin di pesisir perotaan dan perdesaan; dan hubungan antara tingkat kesejahteraan dan tingkat ketahanan pangan rumahtangga nelayan miskin tersebut.

\section{METODOLOGI}

\section{Landasan Teoritis}

Pemerintah Indonesia memiliki beberapa konsep kemiskinan dan kesejahteraan, misalnya, Badan Pusat Statistik (BPS) yang mengukur kemiskinan dengan fokus konsumsi, dan Badan Koordinasi Keluarga Berencana Nasional (BKKBN) yang berfokus pada kesejahteraan keluarga. Lembagalembaga internasional, seperti United Nation Development Programme (UNDP) juga memperhatikan isu pengembangan manusia, yang didefinisikan dengan harapan hidup, tingkat melek huruf, pendidikan dan tingkat daya beli per kapita.

Dalam kaitannya dengan ketahanan pangan rumahtangga nelayan miskin, tingkat kesejahteraan rumah tangga tersebut memiliki peran penting terutama menyangkut aksesibilitas rumah tangga tersebut terhadap pangan. Sebagaimana disampaikan sebelumnya bahwa ketahanan pangan menunjukkan adanya akses setiap individu untuk memenuhi kebutuhan pangan setiap saat terkait dengan upaya meningkatkan kesejahteraannya (Setiawan, 2010). Sementara menurut Siregar (2009b), berkurangnya konsumsi bahan pangan (terutama beras) pada kelompok rumahtangga miskin akan berpengaruh signifikan pada tingkat kesejahteraan mereka, yang biasanya diukur dengan besaran pengeluaran rumahtangga. Dengan tingkat kesejahteraan yang relatif tinggi, maka pemenuhan kebutuhan pangan rumahtangga tersebut akan relatif baik, atau dengan kata lain ketahanan pangannya menjadi lebih baik dibandingkan bila kesejahteraan pada tingkat yang lebih rendah. Atau hubungan yang sebaliknya, dengan tingkat ketahanan pangan yang semakin tinggi, maka hal ini memberikan indikasi bahwa tingkat kesejahteraannya pun akan semakin tinggi pula.

Hal ini pula yang menjadi salah satu argumen mengenai kesejahteraan yang dilihat dari aspek pemenuhan kebutuhan pangan (gizi) (mutrion well being) sebagai salah satu indikator pembangunan manusia yang mempunyai peran penting dalam pembangunan nasional.

Indonesia mengadopsi dan mengadaptasi berbagai rumusan ketahanan pangan dan dituangkan ke dalam UU RI No: 7 tahun 1996 tentang Pangan. Ketahanan pangan didefinisikan sebagai kondisi terpenuhinya pangan bagi rumahtangga yang tercermin dari tersedianya pangan yang cukup (baik jumlah maupun mutunya), aman, merata dan terjangkau (Pasal 1 Undang-Undang Nomor 7 tahun 1996). Ketahanan pangan juga didefinisikan sebagai kondisi terpenuhinya pangan bagi rumah tangga yang meliputi tiga sub sistem utama yaitu: (1) ketersediaan pangan (Food Availability), (2) akses pangan (Food Access), (3) penyerapan pangan (Food Utilization) (Chang, 1997). Seluruh sub sistem harus dipenuhi secara utuh. Jika salah satu sub sistem tidak dipenuhi maka negara tersebut belum dapat dikatakan mempunyai ketahanan pangan yang baik. Walaupun ketersediaan pangan di tingkat nasional cukup, tetapi jika akses individu 
untuk memenuhi kebutuhan pangannya tidak merata, maka ketahanan pangan masih dikatakan rapuh (Siregar, 2009b).

\section{Waktu dan Lokasi Penelitian}

Penelitian ini dilakukan sejak Mei hingga Desember 2010. Sedangkan lokasi penelitian, dalam hal ini ditentukan secara sengaja (purposive), yaitu dengan mengambil kasus di dua lokasi, yaitu: Kelurahan Marunda Baru, Kecamatan Cilincing, Kota Jakarta Utara, Propinsi DKI Jakarta; dan Desa Tanjung Pasir, Kecamatan Teluk Naga, Kabupaten Tanggerang, Propinsi Banten. Secara spesifik kedua lokasi tersebut termasuk memiliki perbedaan dalam hal tipologi wilayah. Kelurahan Marunda (Jakarta Utara) dalam hal ini merupakan wilayah kasus untuk nelayan miskin di pesisir perkotaan, sedangkan Desa Tanjung Pasir (Kabupaten Tanggerang) merupakan wilayah kasus untuk nelayan miskin di pesisir perdesaan.

\section{Penentuan Responden}

Responden dalam penelitian ini adalah responden nelayan miskin di lokasi kasus yang ditentukan secara sengaja (purposive sampling) atau non probability sampling dengan kriteria bahwa mereka adalah merupakan nelayan dari golongan rumahtangga yang miskin yang merupakan penerima Bantuan Langsung Tunai (BLT). Secara keseluruhan, jumlah responden dalam penelitian ini, untuk setiap lokasi kasusnya adalah sebanyak 36 responden nelayan miskin atau total sebanyak 72 reponden. Penentuan jumlah responden ini, selain karena alasan statistika sehingga dapat memenuhi distribusi normal dalam keragaman responden yang dipilih.

\section{Jenis, Sumber dan Teknik Pengumpulan Data}

Jenis data yang digunakan dalam penelitian ini terdiri dari data primer dan data sekunder. Data primer diperoleh melalui wawancara semistruktur dan wawancara mendalam (indept interview) dengan responden. Data primer yang digunakan adalah (1) data-data mengenai tingkat kesejahteraan rumahtangga nelayan miskin yang terdiri dari kesehatan dan gizi, kekayaan materi dan pengetahuan; dan (2) data-data mengenai tingkat ketahanan pangan rumahtangga nelayan miskin yang terdiri dari ketersediaan pangan, akses pangan dan pemanfaatan pangan. Secara rinci data-data tersebut dapat dilihat pada Tabel 3 dan Tabel 4. Sementara data sekunder diperoleh melalui penelusuran berbagai kepustakaan dan dokumen dari instansi terkait dan berbagai informasi lainnya yang relevan dengan tujuan penelitian.

\section{Metoda Analisis Data}

Data yang diperoleh dianalisis dengan statistik deskriptif (tabel dan grafik), sedangkan untuk menguji hubungan anatara peubah tingkat ketahanan pangan dan tingkat kesejahteraan rumah tangga nelayan miskin dilakukan menggunakan analisis pendekatan statistika non-

$$
r_{s}=1-\frac{6 \sum d^{2}}{N\left(N^{2}-1\right)}
$$

dimana:

$$
\begin{aligned}
\mathrm{rs}= & \text { Koefisien korelasi Rank Spearman / } \\
& \text { Coefficient of Rank Spearman correlation } \\
\mathrm{d}= & \text { Perbedaan ranking antara peubah } \\
& \text { yang diuji / Difference of rank among } \\
& \text { variables }
\end{aligned}
$$

$\mathrm{N}=$ Jumlah sampel/Number of sample

parametrik menggunakan pengujian korelasi Rank-Spearman (Levin and Fox, 2007), dengan rumus sebagai berikut:

\section{Pengukuran Tingkat Kesejahteraan}

Seiring dengan perubahan masa, indikator-indikator kesejahteraan dalam ukuran obyektif mengalami pergeseran 
ke arah diferensiasi yang disertai kecenderungan beralih dari interpretasi indikator pembangunan statis ke dinamis. Hal ini dapat dilihat dari perbandingan antara ukuran (indikator) kesejehteraan yang diperlihatkan oleh Honable (1979) dalam Mc.
Crackem (1988) pada Tabel 1 dengan BPS pada Tabel 2.

Kriteria kesejahteraan (kebalikan dari kemiskinan) Honable tersebut hingga saat ini secara dinamis masih terus berkembang. Kriteria yang relatif baru

Tabel 1. Ukuran Kemakmuran (Kesejahteraan) di daerah Pedesaan di Jawa pada Era Lama (Kebalikannya sebagai Ukuran Kemiskinan)*)

Table 1. Measurement of Welfare at Rural in Java during the Past Period (Reservad of the Poor Measurment)*

\begin{tabular}{|c|c|c|c|}
\hline \multirow{2}{*}{$\begin{array}{l}\text { Indikator / } \\
\text { Indicators }\end{array}$} & \multicolumn{3}{|c|}{ Tingkat Kemakmuran (Kesejahteraan)/ level of welfare } \\
\hline & Rendah/ low & Menengah/middle & Tinggi/ high \\
\hline Rumah / house & Bambu/ Bamboo & Kombinasi/combination & Bata dan plester/brick and plaster \\
\hline Kamar-kamar/ rooms & 1-2, kecil/1-2, small & $\begin{array}{l}\text { Banyak,sedang/ } \\
\text { many, medium }\end{array}$ & Banyak, besar/many, large \\
\hline Lantai / floor & Tanah/Ground & $\begin{array}{l}\text { Bata ditutup semen, blok- } \\
\text { blok batu kapur/ brick } \\
\text { covered cement, limestone } \\
\text { blocks }\end{array}$ & $\begin{array}{l}\text { Semen yang dipoles Tegel/keramik/ } \\
\text { cement covered tiles/ceramic }\end{array}$ \\
\hline Atap / roof & $\begin{array}{l}\text { Jerami, daun } \\
\text { kelapa/Straw, } \\
\text { coconut leaves }\end{array}$ & Tanah liat/clay & Semen/keramik/cement/ceramic \\
\hline Jendela / window & Tidak ada/ nothing & Kayu/wood & $\begin{array}{l}\text { Kerangka kayu dengan panel kaca/ } \\
\text { wood frame with glass panel }\end{array}$ \\
\hline Tempat tidur / bed & Tikar/mats & $\begin{array}{l}\text { Dari bambu dengan alas } \\
\text { tikar/ bamboo pedestaled } \\
\text { mat }\end{array}$ & $\begin{array}{l}\text { Tempat tidur kayu atau besi/ } \\
\text { dengan kasur dan kelambu (ber } \\
\text { AC) / wood or metal beds with } \\
\text { mattresses and mosquito nets (AC) }\end{array}$ \\
\hline Penerangan / lights & $\begin{array}{l}\text { Lampu minyak/Oil } \\
\text { lamp }\end{array}$ & $\begin{array}{l}\text { Lampu patromak/ pumped } \\
\text { lamp }\end{array}$ & Generator/generator \\
\hline $\begin{array}{l}\text { Sumber Air / source } \\
\text { of water }\end{array}$ & $\begin{array}{l}\text { Sumur tetangga, } \\
\text { sungai, mata air/ } \\
\text { neighboring wells, / } \\
\text { rivers,springs }\end{array}$ & $\begin{array}{l}\text { Sumur sendiri atau dengan } \\
\text { pompa tangan/ owned } \\
\text { wells or with hand pump }\end{array}$ & $\begin{array}{l}\text { Sumur sendiri atau dengan pompa } \\
\text { listrik/ owned wells or with electric } \\
\text { pump }\end{array}$ \\
\hline Jamban / toilet & $\begin{array}{l}\text { Di luar,terbuka/ } \\
\text { outside, opened }\end{array}$ & $\begin{array}{l}\text { Di luar tertutup/ } \\
\text { outside, closed }\end{array}$ & Dalam rumah/inside \\
\hline $\begin{array}{l}\text { Transportasi / } \\
\text { transportation }\end{array}$ & Tidak ada/nothing & $\begin{array}{l}\text { Sepeda, kereta kuda/ } \\
\text { bicylces, horse-drawn } \\
\text { carriage }\end{array}$ & $\begin{array}{l}\text { Sepeda motor, truk, mini bus/ } \\
\text { motorcycle, truck, minibus }\end{array}$ \\
\hline $\begin{array}{l}\text { Sarana Hiburan/ } \\
\text { entertainment }\end{array}$ & Tidak ada/ nothing & Radio tape/radio tape & TV/TV \\
\hline $\begin{array}{l}\text { Minuman yang } \\
\text { disajikan untuk } \\
\text { pewawancara / } \\
\text { beverage for } \\
\text { interviewer }\end{array}$ & Tidak ada/ nothing & $\begin{array}{l}\text { Teh manis, minuman } \\
\text { manis lainnya/tea, other } \\
\text { beverages }\end{array}$ & $\begin{array}{l}\text { Teh atau kopi disertai makanan } \\
\text { kecil/tea or coffee with snack }\end{array}$ \\
\hline
\end{tabular}

Sumber: Honadle (1979) dalam Mc.Crackem (1988)/Source : Honadle (1979) in Mc.Crackem (1988)

*) Indikator-indikator ini dapat diidentifikasi oleh peneliti berpengalaman yang mempunyai pengetahuan cukiup mengenai keadaan setempat, atau penduduk setempat dapat membantu mengidentifikasi berbagai kemungkinan pengembangan indikator-indikator tersebut sesuai dengan perubahan waktu.

*) This indicators can be identified by researchers who have knowledge about the situation or the people can help to identify of increasing of indicators according to change of time. 
untuk mengukur kemiskinan (kebalikan kesejahteraan) pada rumahtangga miskin telah ditetapkan oleh BPS (2006) berdasarkan kriteria tingkat pendapatan per bulan dan 14 kriteria lainnya yang digunakan dalam rangka penyaluran Bantuan Langsung Tunai (BLT) seperti tertera pada Tabel 2.

Secara sederhana, kategorisasi rumahtangga miskin dari pendekatan BPS ini dilakukan berdasarkan pendapatan rumahtangga per bulan, yaitu: (1) sangat miskin bila kurang dari Rp. 480.000,-; (2) miskin, antara Rp. 480.000,- - Rp. 700.000,; dan (3) hampir miskin, yaitu lebih dari Rp. 700.000,-. Sedangkan 14 kriteria lainnya tertera pada Tabel 2.

Di samping kedua kriteria di atas, pengukuran tingkat kesejahteraan yang berkembang pada saat ini, diantaranya

Tabel 2. Kriteria Kemiskinan (Kebalikan Kesejahteraan) Menurut BPS 2006

Table 2. The Criteria of Poor (Reverse of Welfare) According to CBS 2006

\begin{tabular}{cl}
\hline No. & \multicolumn{1}{c}{ Kriteria/criterias } \\
\hline 1 & $\begin{array}{l}\text { Luas lantai bangunan tempat tinggal yang dimanfaatkan untuk aktivitas sehari-hari/ } \\
\text { the floor area of house can be used for activities everyday }\end{array}$ \\
2 & $\begin{array}{l}\text { Jenis lantai bangunan tempat tinggal terluas terdiri dari tanah/bambu/kayu } \\
\text { berkualitas rendah/ the type of house's widest floor consist of ground / bamboo / } \\
\text { wood with low quality }\end{array}$ \\
3 & $\begin{array}{l}\text { Jenis dinding bangunan tempat tinggal terluas terdiri dari bambu/kayu berkualitas } \\
\text { rendah/ The type of house's widest walls consist of bamboo/wood with low quality }\end{array}$ \\
4 & $\begin{array}{l}\text { Fasilitas tempat buang air besar (jamban/kakus) digunakan secara bersama-sama } \\
\text { atau menggunakan secara umum/ public toilet facilities (toilet / latrine) }\end{array}$ \\
5 & $\begin{array}{l}\text { Sumber air minum adalah mata air yang tidak terlindung/sungai/air hujan/ Source of } \\
\text { drinking water is the spring which is not protected / river / rain water }\end{array}$ \\
6 & $\begin{array}{l}\text { Sumber penerangan utama bukan listrik/source of non-electric lighting } \\
7\end{array}$ \\
Jenis bahan bakar untuk memasak sehari-hari dari kay/arang/minyak tanah/ Type \\
of fuel for cooking consist of wood / charcoal / kerosene
\end{tabular}

8 Jarang atau tidak pernah membeli daging/ayam/susu setiap minggunya/ rarely or never buy meat / chicken / milk everyweek

9 Anggota rumahtangga hanya mampu menyediakan makan dua kali dalam sehari/ member of household only eat twice everyday

10 Tidak mampu membeli pakaian baru minimal satu stel setiap tahun/ they can not buy new clothes at least one set everyyear

11 Bila jatuh sakit tidak berobat karena tidak ada biaya untuk berobat/not having money for treatment if feel terrible

12 Pekerjaan utama kepala keluarga sebagai buruh kasar dan atau tidak bekerja/the main job of head of household as a labor or jobless

13 Pendidikan tertinggi yang ditamatkan kepala keluarga SD ke bawah/the highest education of head of household is elementary

14 Ada tidaknya barang dalam keluarga yang dapat dijual dengan nilai Rp. 500.000,-/ there're things can be sold with the price Rp. 500.000,- 
adalah seperti yang digunakan oleh Cahyat et al. (2007). Berdasarkan pengukuran ini, tingkat kemiskinan akan sangat terkait erat dengan ukuran tingkat kesejahteraan yang bersifat subyektif dan obyektif. Ukuran kesejahteraan subyektif akan sangat sulit digunakan sebagai acuan kebijakan, karena diukur berdasarkan penilaian perasaan dari responden (rumah tangga) yang sifatnya mudah berubah-ubah dalam jangka pendek; sementara kebijakan memerlukan tenggang waktu relatif lama mulai dari tahapan formulasi hingga tahapan implementasi dan evaluasi.

Di sisi lain, kesejahteraan obyektif lebih dapat digunakan sebagai acuan kebijakan karena diukur berdasarkan indikator-indikator yang lebih terukur dan handal dari perubahan waktu, seperti pemenuhan kebutuhan dasar yang bersifat material maupun bukan material. Ukuran kesejahteraan subyektif ini terdiri dari dua komponen, yaitu: (1) kesejahteraan inti yang mencakup tiga aspek, yaitu: (a) kesehatan dan gizi, (b) kekayaan materi dan (c) pengetahuan; dan (2) kesejahteraan pendukung (lingkungan kesejahteraan) yang mencakup lima aspek, yaitu: (a) lingkungan alam, (b) lingkungan ekonomi, (c) lingkungan sosial, (d) lingkungan politik, dan (e) infrastruktur dan pelayanan.

Masing-masing aspek yang digunakan Cahyat et al., (2007) dalam mengukur kesejahteraan tersebut, baik pada kesejahteraan inti maupun kesejahteraan pendukung memiliki beberapa indikator yang menjadi ukurannya yang sebagian besar memiliki kesemaan dengan kriteria (indikator) kemiskinan versi BPS (2006). Selanjutnya aspek dan indikator tersebut digunakan sebagai dasar pengukuran peubah tingkat kesejahteraan rumah tangga nelayan, seperti tertera pada Tabel 3.

Tabel 3. Indikator dan Atribut Tingkat Kesejahteraan Rumahtangga Nelayan Miskin

Table 3. Indicators and Atributes of Welfare Level at Poor Fisher Household used in the Research

\section{Indikator/indicators}

1.1 Kesehatan dan Gizi/ Health and Nutrition

\subsection{Kekayaan Materi/ Materials Property}

1.3 Pengetahuan/knowledge

\section{Atribut/Attributes}
(a) Pemenuhan kebutuhan pelayanan kesehatan / Meeting needs of health care
(b) Pemenuhan kebutuhan makan/ Meeting needs of food
(c) Kondisi sanitasi tempat tinggal/ House's sanitation condition
(d) Kondisi sumber air minum / Condition of drinking water source

(a) Tingkat pendapatan rumah tangga/ Household's income

(b) Kondisi bangunan tempat tinggal/ Condition of house's buildings

(c) Sarana penerangan/ Lighting facility

(d) Penggunaan jenis bahan bakar untuk masak/ Using of fuel for cooking

(e) Pemenuhan kebutuhan sandang/ Meeting of needs of clothing

(f) Pemenuhan (akses) pekerjaan /Acceessing for jobs

(g) Pemilikan aset ekonomi/Ownership of economic assets
(a) Tingkat pendidikan formal/ level of formal education
(b) Jumlah anak yang bersekolah atau putus sekolah/ Number of children who study at school or drop out of school
(c) Pengetahuan informal/Informal Knowledge 
Masing-masing atribut akan diukur dengan menggunakan pen-skor-an (skoring) mengikuti metode skala Likert dengan memberi skor ganjil (Neuman, 2006); dalam hal ini skor diberikan dengan interval 1 - 5 dimana 1 untuk atributatribut dengan kondisi rendah; 2 untuk atribut-atribut dengan kondisi agak rendah, 3 untuk atribut-atribut dengan kondisi sedang, 4 untuk atribut-atribut dengan kondisi agak tinggi dan 5 untuk atributatribut dengan kondisi tinggi .

Secara keseluruhan, berdasarkan skor $(1-3)$ dari atribut tersebut akan diperoleh skor minimum sebesar 14 dan skor maksimum sebesar 70 . Dengan demikian, peubah tingkat kesejahteraan rumah tangga nelayan miskin dapat dibagi menjadi lima kategori, yaitu:

(1) Tingkat kesejahteraan rendah atau miskin (jika skor 14,0 - 25,2)

(2) Tingkat kesejahteraan agak rendah atau agak miskin (jika skor 25,3-36,4)

(3) Tingkat kesejahteraan sedang atau hampir miskin (jika skor 36,5-47,6)

(4) Tingkat kesejahteraan agak tinggi atau agak kaya (jika skor 47,7-58,8)

(5) Tingkat kesejahteraan tinggi atau kaya (jika skor 58,9-70,0).

\section{Pengukuran Tingkat Ketahanan Pangan Rumahtangga}

Ketahanan pangan merupakan konsep yang multidimensi, yaitu meliputi mata rantai sistem pangan dan gizi mulai dari produksi, distribusi, konsumsi dan status gizi. Situasi sistem ketahanan pangan rumahtangga dimulai dari ukuran yang dikembangkan dari berbagai indikator. Berdasarkan sistem pangan dan gizi tersebut Chang (1997) merangkum beragam indikator ketahanan pangan rumahtangga khususnya rumahtangga "pertanian" sesuai dengan aspek ketersediaan, akses dan konsumsi/ pemanfaatan pangan dalam sebuah kerangka konseptual, yaitu sebagai berikut:

(1) Aspek ketersediaan pangan tergantung tergantung pada sumber daya alam, fisik dan manusia serta produksi pertanian maupun non pertanian. Dalam hal ini indikator yang dipakai untuk menjelaskan sumber daya alam adalah curah hujan, kualitas tanah, ketersediaan air dan akses terhadap sumber daya hutan, sumber daya fisik seperti pemilikan ternak atau ikan, akses infrastruktur, pemilikan sarana pertanian, pemilikan tanah. Indikator sumber daya manusia meliputi rasio ke tergantungan, pendidikan, besar keluarga dan umur keluarga. Indikator produksi adalah luas tanam, luas lahan beririgasi, akses dan penggunaan input, pola tanam, keragaman tanaman, produksi pangan dan produksi non pangan.

(2) Aspek akses pangan meliputi pendapatan baik dari perikanan dan non perikanan. Indikator yang dipakai adalah total pendapatan, pendapatan dari usaha perikanan, upah, harga pangan, pasar dan akses jalan.

(3) Aspek pemanfaatan pangan adalah konsumsi baik pangan serta status gizi anak maupun dewasa. Indikator konsumsi yang digunakan adalah pengeluaran pangan, konsumsi dan frekuansi pangan. Indikator gizi meliputi kesakitan, akses palayanan kesehatan, akses air bersih dan status sanitasi.

Maxwell dan Frankenberger (1992) menyatakan bahwa pencapaian ketahanan pangan rumahtangga dapat diukur dari berbagai indikator. Indikator tersebut dibedakan menjadi dua kelompok, yaitu: indikator proses dan indikator dampak. Indikator proses menggambarkan situasi pangan yang ditunjukkan oleh ketersediaan dan akses pangan. Indikator dampak digunakan sebagai cerminan konsumsi pangan. Sedangkan indikator ketersediaan pangan berkaitan dengan produksi pertanian, iklim, akses terhadap 
sumber daya alam, praktek pengelolaan lahan, pengembangan institusi, pasar, konflik regional dan kerusuhan sosial. Indikator akses pangan meliputi antara lain sumber pendapatan, akses terhadap kredit modal. Indikator akses pangan juga meliputi strategi rumahtangga untuk memenuhi kekurangan pangan. Strategi tersebut dikenal sebagai coping ability indicator. Indikator dampak meliputi dua kategori, yaitu langsung dan tidak langsung. Indikator dampak secara langsung adalah konsumi dan frekuansi pangan. Indikator dampak secara tidak langsung meliputi penyimpanan pangan dan status gizi.

Dari indikator-indikator ketahanan pangan tersebut, diketahui bahwa ketahanan pangan merupakan konsep multidimensial sehingga tidak ada indikator tunggal yang dapat dipakai untuk mengukur status ketahanan pangan suatu rumahtangga (terlepas dari apakah mereka dari kelompok rumahtangga pertanian atau non pertanian). International Food Policy Research Institut/IFRI (1992) menyatakan Borion dan Shoham menyarankan 20 indikator utama; Maxwell and Frankenberger, dan Seaman, Holt dan Allen masing-masing dengan 20 dan 30 indikator untuk menilai ketahanan pangan rumahtangga.

Selanjutnya ukuran katahanan pangan rumahtangga nelayan yang digunakan dalam penelitian ini dilakukan dengan mengadopsi berbagai konsep dan indikatorindikator pengukuran ketahanan pangan tersebut di atas yang disesuaikan konteksnya dengan kondisi rumahtangga nelayan berserta kegiatan usaha nelayannya, yaitu seperti tertera pada Tabel 4 .

Setiap atribut pada Tabel 4 akan diukur dengan menggunakan pen-skor-an (skoring) mengikuti metode skala Likert dengan memberi skor ganjil (Neuman, 2006); dalam hal ini skor diberikan dengan interval 1 - 5 . Untuk atribut-atribut pada masing-masing indikator (ketersediaan pangan, akses pangan dan pemanfaatan pangan) diberikan skor 1 untuk kondisi rendah; 2 untuk kondisi agak rendah, 3 untuk kondisi sedang, 4 untuk kondisi agak tinggi dan 5 untuk kondisi tinggi .

Tabel 4. Indikator dan Atribut Tingkat Ketahanan Pangan Rumahtangga Nelayan Miskin yang Digunakan dalam Penelitian

Table 4. Indicators and Atributes of Food Security Level at Poor Fisher Household used in the Research

\section{Indikator/indicators Atribut/atributes}

1. Ketersediaan Pangan/ (a) Pendidikan non formal/ Non-formal Education Availability food

(b) Pendidikan formal/ Formal Education

(c) Pengalaman sebagai nelayan/ Experience as a fisher

(d) Pengetahuan mengenai usaha penangkapan ikan/ Knowledge of fishing effort

(e) Pemilikan modal kerja/ Ownership of working capital

(f) Bobot perahu/kapal yang digunakan/Weight of boat / ship used

(g) Produktivitas usaha penangkapan ikan/ The productivity of fishing effort

(h) Jumlah anggota rumahtangga usia $>15$ tahun yang bekerja/ The number of household member who has age $>15$ years who worked

(i) Penjualan bahan pangan di pasar terdekat/ Sales of food in the nearest market

(j) Penjualan bahan pangan di warung terdekat/ Sales of food in the nearest shop

(k) Perolehan bantuan beras untuk masyarakat miskin/raskin/ Having rice aid for the poor household/ raskin 
Lamjutan Tabel 4/Continue Table 4

\begin{tabular}{ll}
\hline Indikator/Indicators & \multicolumn{1}{c}{ Atribut/Atributes } \\
\hline $\begin{array}{l}\text { 2. Akses Pangan/ } \\
\text { Food Access }\end{array}$ & (a) Pendapatan nelayan dari usaha penangkapan ikan/ \\
Fisher's income from the fishing business \\
(b) Pendapatan nelayan dari luar usaha penangkapan ikan/ \\
Fisher's income from outside the fishing business \\
(c) Pendapatan isteri nelayan/ Income fisher's wife \\
(d) Jarak rumah tinggal ke pasar terdekat/ \\
(e) Kistance of household to the nearest market \\
The condition of road to the nearest market \\
(f) Jarak rumah tinggal ke warung terdekat/ \\
(g) Khe distance of household to nearest small shop \\
The condition of road to nearest small shop \\
Food utility \\
(a) Pengeluaran pangan/ Food expenditures \\
(b) Status konsumsi kepala keluarga dan isteri/ \\
(c) Stad of household and wife' consumption \\
(d) Status ISPA balita/anak/ ISPA status of toddler / child \\
(e) Status diare balita/anak/ Status of diarrhea toddler / child \\
(f) Akses pelayanan kesehatan/ Access to health services \\
(g) Akses air bersih/ Access to clean water \\
(h) Status sanitasi lingkungan/ The status of environmental sanitation
\end{tabular}

Secara keseluruhan, berdasarkan skor dari indikator tersebut akan diperoleh skor minimum sebesar 26 dan skor maksimum sebesar 130 . Dengan demikian, peubah tingkat ketahanan pangan rumah tangga nelayan miskin dapat dikategori menjadi:

(1) Rawan pangan jika skor antara 26,0-46,8

(2) Agak rawan pangan jika skor antara 46,9-67,6

(3) Hampir rawan pangan jika skor antara $67,7-88,4$

(4) Agak tahan pangan jika skor antara $88,5-109,2$

(5) Tahan pangan jika skor antara. 109,3125,0

\section{HASIL DAN PEMBAHASAN}

\section{Profil Kesejahteraan Rumahtangga Nelayan Miskin}

Gambaran tingkat kesejahteraan rumahtangga nelayan miskin di lokasi kasus yang diteliti, baik pada tipologi pesisir perkotaan maupun perdesaan diperkirakan berdasarkan skor komposit dari tiga dimensi, yaitu: (1) Dimensi kesehatan dan gizi; (2) Dimensi Kekayaan materi; dan (3) Dimensi pengetahuan, seperti tertera pada Tabel 5 dan Tabel 6 .

Dari Tabel 5 diketahui bahwa menurut dimensinya, tingkat kesejahteraan rumahtangga nelayan miskin baik di perkotaan maupun perdesaan tersebar ke dalam tiga kategori, yaitu: rendah, 
Tabel 5. Skor dan Kategori Setiap Dimensi Kesejahteraan Rumahtangga Nelayan Miskin menurut Tipologi Kemiskinan Perkotaan dan Perdesaan, 2010

Table 5. Score and Category of each Dimension of Welfare at Poor Fisher Household According to Poor typology of Urban and Rural Area, 2010

\begin{tabular}{|c|c|c|c|c|c|}
\hline \multirow{3}{*}{$\begin{array}{c}\text { Indikator } \\
\text { Kesejahteraan/ } \\
\text { welfare indicators }\end{array}$} & \multirow{3}{*}{$\begin{array}{l}\text { Kategori/ } \\
\text { categories }\end{array}$} & \multirow{3}{*}{$\begin{array}{l}\text { Selang Skor/ } \\
\text { Score }\end{array}$} & \multicolumn{2}{|c|}{$\begin{array}{l}\text { Tipologi Kemiskinan/ } \\
\text { Type of poor }\end{array}$} & \multirow[b]{2}{*}{$\begin{array}{l}\text { Rata-rata } \\
\text { Gabungan/ } \\
\text { Average }\end{array}$} \\
\hline & & & $\begin{array}{c}\text { Perisir } \\
\text { Perkotaan/ } \\
\text { Coastal } \\
\text { Urban Area } \\
\end{array}$ & $\begin{array}{c}\text { Pesisir } \\
\text { Perdesaan/ } \\
\text { Coastal } \\
\text { Rural Area } \\
\end{array}$ & \\
\hline & & & \multicolumn{3}{|c|}{ Persentase (\%) } \\
\hline \multirow{6}{*}{$\begin{array}{l}\text { Kesehatan dan Gizi/ } \\
\text { Health and Nutrition }\end{array}$} & Rendah/low & $4,00-7,20$ & 77,78 & 22,22 & 50,00 \\
\hline & $\begin{array}{l}\text { Agak Rendah/ } \\
\text { A bit low }\end{array}$ & $7,30-10,40$ & 13,89 & 75,0 & 44,44 \\
\hline & $\begin{array}{l}\text { Sedang/ } \\
\text { Medium }\end{array}$ & $10,50-13,60$ & 8,33 & 2,78 & 5,56 \\
\hline & $\begin{array}{l}\text { Agak Tinggi/ } \\
\text { A bit high }\end{array}$ & $13,70-16,80$ & 0,0 & 0,0 & 0,0 \\
\hline & Tinggi/High & $16,90-20,00$ & 0,0 & 0,0 & 0,0 \\
\hline & umlah/Total & & 100,00 & 100,00 & 100,00 \\
\hline \multicolumn{3}{|c|}{ Jumlah Sampel ( $n) /$ number of sample } & 36 & 36 & 72 \\
\hline \multirow{6}{*}{$\begin{array}{l}\text { Kekayaan Materi/ } \\
\text { Materials Property }\end{array}$} & Rendah/Low & $7,00-12,60$ & 55,56 & 13,89 & 34,72 \\
\hline & $\begin{array}{l}\text { Agak Rendah/ } \\
\text { A bit low }\end{array}$ & $12,70-18,20$ & 38,89 & 52,78 & 45,83 \\
\hline & $\begin{array}{l}\text { Sedang/ } \\
\text { Medium }\end{array}$ & $18,30-23,80$ & 5,56 & 33,33 & 19,44 \\
\hline & $\begin{array}{l}\text { Agak Tinggi/A } \\
\text { bit igh }\end{array}$ & $23,90-29,40$ & 0,0 & 0,0 & 0,0 \\
\hline & Tinggi/High & $29,50-35,00$ & 0,0 & 0,0 & 0,0 \\
\hline & umlah/Total & & 100,00 & 100,00 & 100,00 \\
\hline \multicolumn{3}{|c|}{ Jumlah Sampel ( $n) /$ Number of Sample } & 36 & 36 & 72 \\
\hline \multirow{6}{*}{$\begin{array}{l}\text { Pengetahuan/ } \\
\text { Knowledge }\end{array}$} & Rendah/low & $3,00-5,40$ & 91,67 & 30,56 & 61,11 \\
\hline & $\begin{array}{l}\text { Agak Rendah/ } \\
\text { A bit low }\end{array}$ & $5,50-7,80$ & 5,56 & 66,67 & 36,11 \\
\hline & $\begin{array}{l}\text { Sedang/ } \\
\text { Medium }\end{array}$ & $7,90-10,20$ & 2,78 & 2,78 & 2,78 \\
\hline & $\begin{array}{l}\text { Agak tinggi/ } \\
\text { A bit high }\end{array}$ & $10,30-12,60$ & 0,0 & 0,0 & 0,0 \\
\hline & Tinggi/High & $12,70-15,00$ & 0,0 & 0,0 & 0,0 \\
\hline & umlah/Total & & 100,00 & 100,00 & 100,00 \\
\hline \multicolumn{3}{|c|}{ Jumlah Sampel ( $n) /$ Number of Sample } & 36 & 36 & 72 \\
\hline
\end{tabular}

Sumber: Data Primer, Diolah (2010)/Source : Primary Data(2010)

agak rendah dan sedang. Sementara tidak satu pun rumahtangga nelayan miskin yang termasuk dalam kategori agak tinggi dan tinggi. Bila dibandingkan diantara ketiga kategori tesebut (rendah, agak rendah dan sedang), baik dimensi kesehatan dan gizi, kekayaan materi maupun pengetahuan didominasi kategori rendah dan agak rendah. Namun dari kedua kategori tersebut, dimensi-dimensi kesjahteraan rumahtangga 
nelayan miskin di perkotaan termasuk dalam kategori yang relatif lebih rendah dibandingkan perdesaan, karena untuk perkotaan lebih didominasi oleh kategori yang rendah, sedangkan perdesaan didominasi oleh kategori agak rendah.

Selanjutnya, berdasarkan skor komposit dari keseluruhan dimensi kesejahteraan dapat diketahui gambaran kesejahteraan rumahtangga nelayan miskin untuk tipologi perkotaan dan perdesaan, seperti tertera pada Tabel 6.

Dari Tabel 6 dapat diketahui bahwa sebagian besar (52,78\%) tingkat kesejahteraan rumah tangga nelayan menurut tiplogi kemiskinan pesisir perkotaan maupun pesisir perdesaan termasuk dalam kategori rendah. Jika dibandingkan menurut kedua tipologi tersebut, ditemukan bahwa tingkat kesejahteraan rumah tangga nelayan miskin di pesisir perkotaan didominasi oleh kategori rendah, sedangkan di pesisir perdesaan didominasi oleh kategori agak rendah. Hal ini bermakna bahwa tingkat kesehatan dan gizi, tingkat kekayaan materi dan tingkat pengetahuan pada rumah tangga nelayan miskin di pesisir perkotaan relatif rendah dibandingkan dengan pesisir perdesaan. Kenyataan ini menunjukkan bahwa baik mereka yang di perkotaan maupun perdesaan terbelenggu dalam jebakan kesejahteraan yang rendah, dan secara relatif kondisinya lebih berat bagi mereka yang berada pada tipologi kemiskinan di perkotaan (Sherraden, 2006).

Temuan penelitian ini selaras dengan hasil penelitian Ritonga (2006), bahwa tingkat kesejahteraan rumah tangga miskin di perdesaan relatif lebih tinggi dibandingkan dengan rumah tangga miskin di perkotaan. Hal ini karena rumah tanga miskin di perdesaan memiliki mekanisme pemecahan masalah melalui kekuatan modal sosial (social capital) sebagai jaring pengaman social (social safety net) Modal sosial yang masih aktual, yaitu: budaya gotong royong, saling tolong-menolong, saling bantu-membantu antara satu rumah tangga dengan yang lainnya dalam memanfaatkan sumberdaya alam sehingga

Tabel 6. Tingkat Kesejahteraan Nelayan Menurut Tipologi Kemiskinan di Perkotaan dan Perdesaan, 2010

Table 6. Welfare Level According to Poor Typology of Urban and Rural Area, 2010

\begin{tabular}{|c|c|c|c|c|c|}
\hline \multirow{4}{*}{$\begin{array}{c}\text { Peubah Terikat/ } \\
\text { dependent } \\
\text { variable }\end{array}$} & \multirow{4}{*}{$\begin{array}{l}\text { Kategori/ } \\
\text { categories }\end{array}$} & \multirow{4}{*}{$\begin{array}{c}\text { Selang Skor/ } \\
\text { score }\end{array}$} & \multicolumn{2}{|c|}{ Tipologi Kemiskinan/type of poor } & \multirow{4}{*}{$\begin{array}{c}\text { Rata-rata } \\
\text { Gabungan/ } \\
\text { average }\end{array}$} \\
\hline & & & $\begin{array}{c}\text { Perisir Perkotaan/ } \\
\text { coastal }\end{array}$ & $\begin{array}{c}\text { Pesisir } \\
\text { Perdesaan/ }\end{array}$ & \\
\hline & & & Urban area & $\begin{array}{c}\text { coastal rural } \\
\text { area }\end{array}$ & \\
\hline & & & \multicolumn{2}{|c|}{ Persentase (\%) } & \\
\hline \multirow{6}{*}{$\begin{array}{l}\text { Tingkat } \\
\text { Kesejahteraan } \\
\text { Rumahtangga } \\
\text { NelayanMiskin } \\
\left(\mathrm{Y}_{1}\right) / \text { /level of poor } \\
\text { fisher's welfare }\end{array}$} & Rendah/low & $14,0-19,5$ & 77,78 & 27,78 & 52,78 \\
\hline & $\begin{array}{c}\text { Agak Rendah/a } \\
\text { bit low }\end{array}$ & $19,6-25,2$ & 16,67 & 61,11 & 38,89 \\
\hline & $\begin{array}{l}\text { Sedang/ } \\
\text { medium }\end{array}$ & $25,3-30,9$ & 5,56 & 11,11 & 8,33 \\
\hline & $\begin{array}{l}\text { Agak Tinggi/a } \\
\text { bit high }\end{array}$ & $31,0-36,6$ & 0,00 & 0,00 & 0,0 \\
\hline & Tinggi/high & $36,7-42,0$ & 0,00 & 0,00 & 0,0 \\
\hline & & Jumlah/total & 100,00 & 100,00 & 100,00 \\
\hline \multicolumn{3}{|c|}{ Jumlah Sampel (n)/number of sample } & 36 & 36 & 72 \\
\hline
\end{tabular}

Sumber: Data Primer, Diolah (2010)/Source : Primary Data(2010) 
dapat mengurangi pengeluaran setiap harinya (Lawang, 2005; Hasbullah, 2006). Di samping itu, rumahtangga miskin di perdesaan masih menganut "ekonomi afeksi" atau memiliki moral ekonomi (Bakhit et al., 2001). Sebaliknya rumah tangga miskin di perkotaan tidak memiliki alternatif lain sehingga kebutuhan sehari-hari diperoleh dengan membeli dari pendapatannya yang terbatas dan kurang menentu (Solahuddin dan Fatika, 2006).

\section{Keragaan Ketahanan Pangan Rumahtangga Nelayan Miskin}

Kondisi tingkat ketahanan pangan rumahtangga nelayan miskin diperkirakan melalui skor komposit dari tiga dimensi/ komponen, yaitu: (1) ketersediaan pangan; (2) akses pangan; dan (3) pemanfaatan pangan. Kondisi masing-masing dimensi ketahanan pangan rumahtangga nelayan tersebut, baik untuk tipologi pesisir perkotaan maupun perdesaan dapat dilihat pada Tabel 7.

Tabel 7. Skor dan Kategori Dimensi Ketahanan Pangan Rumahtangga Responden Menurut Tipologi Kemiskinan, 2010

Table 7. Score and Category Dimension of Food Security of Respondent Household by Poor Category, 2010

\begin{tabular}{|c|c|c|c|c|c|}
\hline \multirow{3}{*}{$\begin{array}{c}\text { Indikator } \\
\text { Ketahanan } \\
\text { Pangan/Food } \\
\text { Security Indicators }\end{array}$} & \multirow{3}{*}{$\begin{array}{l}\text { Kategori/ } \\
\text { Categories }\end{array}$} & \multirow{3}{*}{$\begin{array}{l}\text { Selang Skor/ } \\
\text { Score }\end{array}$} & \multicolumn{2}{|c|}{ Tipologi Kemiskinan/Type of Poor } & \multirow[b]{2}{*}{$\begin{array}{l}\text { Rata-rata } \\
\text { Gabungan/ } \\
\text { Average }\end{array}$} \\
\hline & & & $\begin{array}{l}\text { Perisir Perkotaan/ } \\
\text { Coastal Urban Area }\end{array}$ & $\begin{array}{l}\text { Pesisir Perdesaan/ } \\
\text { Coastal Rural Area }\end{array}$ & \\
\hline & & & \multicolumn{3}{|c|}{ Persentase (\%) } \\
\hline \multirow{5}{*}{$\begin{array}{l}\text { Ketersediaan } \\
\text { Pangan } \\
\text { Rumahtangga } \\
\text { Nelayan Miskin } \\
\left(Y_{2.1}\right) / \text { Food } \\
\text { Availability of Poor } \\
\text { Fisher's Household }\end{array}$} & Rendah/Low & $10,00-18,00$ & 69,44 & 47,22 & 58,33 \\
\hline & $\begin{array}{l}\text { Agak Rendah/ } \\
\text { A bit low }\end{array}$ & $18,01-26,00$ & 25,0 & 50,00 & 37,50 \\
\hline & $\begin{array}{l}\text { Sedang/ } \\
\text { Medium }\end{array}$ & $26,01-34,00$ & 5,56 & 2,78 & 4,17 \\
\hline & $\begin{array}{l}\text { Agak Tinggi/ } \\
\text { A bit high }\end{array}$ & $34,01-42,00$ & 0,00 & 0,00 & 0,00 \\
\hline & Tinggi/High & $42,01-50,00$ & 0,00 & 0,00 & 0,00 \\
\hline \multicolumn{3}{|l|}{ Jumlah/Total } & 100,00 & 100,00 & 100,00 \\
\hline \multicolumn{3}{|c|}{ Jumlah Sampel ( $\mathrm{n}) /$ Number of Sample } & 36 & 36 & 72 \\
\hline \multirow{5}{*}{$\begin{array}{l}\text { Aksesibilitas } \\
\text { Pangan } \\
\text { Rumahtangga } \\
\text { Nelayan Miskin } \\
\left(\mathrm{Y}_{2.2}\right) \text { /Food Access } \\
\text { of Poor Fisher's } \\
\text { Household }\end{array}$} & Rendah/low & $7,00-12,60$ & 47,22 & 16,67 & 31,94 \\
\hline & $\begin{array}{l}\text { Agak Rendah/ } \\
\text { A bit low }\end{array}$ & $12,70-18,20$ & 44,44 & 55,56 & 50,00 \\
\hline & $\begin{array}{l}\text { Sedang/ } \\
\text { Medium }\end{array}$ & $18,30-23,80$ & 8,33 & 27,78 & 18,06 \\
\hline & $\begin{array}{l}\text { Agak Tinggi/ } \\
\text { A bit high }\end{array}$ & $23,90-29,40$ & 0,00 & 0,00 & 0,00 \\
\hline & Tinggi/High & $29,50-35,00$ & 0,00 & 0,00 & 0,00 \\
\hline \multicolumn{3}{|l|}{ Jumlah/total } & 100,00 & 100,00 & 100,00 \\
\hline \multicolumn{3}{|c|}{ Jumlah Sampel (n)/ Number of Sample } & 36 & 36 & 72 \\
\hline \multirow{5}{*}{$\begin{array}{l}\text { Pemanfaatan } \\
\text { Pangan } \\
\text { Rumahtangga } \\
\text { Nelayan Miskin } \\
\left(\mathrm{Y}_{2.3}\right) / \text { food utility } \\
\text { of poor fisher's } \\
\text { household }\end{array}$} & Rendah/low & $8,00-16,40$ & 55,56 & 19,44 & 37,50 \\
\hline & $\begin{array}{l}\text { Agak Rendah/ } \\
\text { A bit low }\end{array}$ & $16,41-22,80$ & 36,11 & 63,89 & 50,00 \\
\hline & $\begin{array}{l}\text { Sedang/ } \\
\text { medium }\end{array}$ & $22,81-29,20$ & 8,33 & 16,67 & 12,50 \\
\hline & $\begin{array}{l}\text { Agak Tinggi/ } \\
\text { A bit high }\end{array}$ & $29,2135,60$ & 0,00 & 0,00 & 0,00 \\
\hline & Tinggi/High & $35,61-40,00$ & 0,00 & 0,00 & 0,00 \\
\hline \multicolumn{3}{|l|}{ Jumlah/Total } & 100,00 & 100,00 & 100,00 \\
\hline \multicolumn{3}{|c|}{ Jumlah Sampel (n)/ Number of Sample } & 36 & 36 & 72 \\
\hline
\end{tabular}

Sumber: Data Primer, Diolah (2010)/Source : Primary Data (2010) 
Tabel 7 menunjukkan bahwa secara keseluruhan untuk kedua tipologi kemiskinan perkotaan dan perdesaan sebagian besar $(58,33 \%)$ termasuk dalam kategori tingkat ketersediaan pangan yang rendah. Namun bila dilihat menurut tipologinya, tingkat ketersediaan pangan rumah tangga nelayan miskin di pesisir perkotaan relatif lebih rendah dibandingkan dengan di pesisir perdesaan. Hal ini terlihat dari tingkat ketersediaan pangan rumah tangga nelayan miskin di pesisir perkotaan yang didominasi oleh kategori yang rendah $(69,44 \%)$, sedangkan di pesisir perdesaan menyebar dengan persentase yang sama untuk kategori rendah $(47,22 \%)$ dan agak rendah (50,00\%). Kondisi ini menggambarkan bahwa secara keseluruhan maupun menurut tipologinya (pesisir perkotaan dan perdesaan) rumah tangga nelayan miskin menghadapi permasalahan ketersediaan pangan yang mengkhawatirkan. Kekhawatiran tersebut akan lebih tampak lagi pada rumah tangga nelayan miskin di pesisir perkotaan.

Berbeda dengan kondisi ketersediaan pangan, rumahtangga nelayan miskin secara keseluruhan maupun menurut tipologi kemiskinannya justru didominasi oleh kondisi tingkat aksesibilitas pangan yang agak rendah. Secara keseluruhan sebanyak $50 \%$ rumahtangga nelayan miskin yang mengalami kondisi aksesibilitas pangan yang agak rendah. Sementara menurut tipologinya, tingkat aksesibilitas pangan rumahtangga nelayan miskin di pesisir perkotaan lebih rendah dibandingkan dengan di pesisir perdesaan. Terlihat bahwa tingkat aksesibilitas pangan untuk rumahtangga nelayan miskin di pesisir perkotaan tersebar dalam kategori rendah $47,22 \%)$ dan agak rendah (44,44\%), sedangkan di pesisir perdesaan tersebar dalam kategori agak rendah (50,00\%) dan rendah $(31,94)$. Informasi tersebut bermakna bahwa rumahtangga nelayan miskin, baik secara keseluruhan maupun menurut tipologinya menghadapi permasalahan yang dapat dikatakan serius dalam hal memperoleh akses terhadap pangan bagi rumahtangganya, dan kondisinya lebih serius lagi bagi rumahtangga nelayan miskin di pesisir perkotaan.

Selanjutnya dalam hal pemanfaatan pangan, rumahtangga nelayan miskin secara keseluruhan tersebar dalam kategori rendah, sedang dan tinggi yang secara relatif mendekati sama besarnya. Mereka yang tergolong dalam kategori pemanfaatan pangan yang rendah sebesar $37,50 \%$, agak rendah sebesar $50 \%$ dan sedang sebesar $12,50 \%$. Namun secara relatif menurut tipologi kemiskinannya, terdapat kondisi yang berlawanan dalam hal pemanfaatan pangan. Rumahtangga nelayan miskin di pesisir perkotaan sebagian besar $(55,56 \%)$ mengalami kondisi tingkat pemanfaatan pangan rendah, sebaliknya rumahtangga nelayan miskin di pesisir perdesaan justru sebagian besar memiliki kondisi yang tergolong dalam kategori agak rendah (63,89\%). Hal berarti bahwa secara relatif rumahtangga nelayan miskin di pesisir perkotaan lebih memiliki permasalahan dalam hal pemanfaatan pangan dibandingkan dengan di pesisir perdesaan. Namun demikian kedua tipologi rumahtangga nelayan miskin tersebut adalah samasama menghadapi permasalahan dalam pemanfaatan pangannya.

Secara keseluruhan dari ketiga skor dimensi ketahanan pangan tersebut di atas dapat diketahui gambaran tingkat ketahanan pangan rumahtangga nelayan miskin, baik untuk tipologi pesisir perkotaan maupun pesisir pedeesaan, seperti tertera pada Tabel 8 .

Dari Tabel 8 diketahui bahwa sebagian besar (59,72\%) rumahtangga nelayan miskin dikedua tipologi kemiskinan (pesisir perkotaan dan perdesan) secara keseluruhan tergolong dalam kategori agak rawan pangan. Hal ini mengindikasikan bahwa dalam memenuhi kebutuhan pangannya, rumahtangga nelayan miskin kedua tipologi tersebut menghadapi permasalahan dalam ketersediaan pangan, akses pangan dan pemanfaatan pangan. Sisanya relatif kurang 
menghadapi permasalahan tersebut, sehingga mereka hanya tergolong dalam kategori rawan pangan dan tahan pangan, masing-masing sebanyak $34,72 \%$ dan $5,56 \%$.

Namun bila kita bandingkan antara tipologi kemiskinan yang terdapat di pesisir perkotaan dan perdesaan, ternyata dari Tabel 8 tersebut dapat diketahui bahwa terdapat perbedaan sebaran komposisi tingkat ketahanan pangan rumahtangga nelayan miskin yang ada. Tampak bahwa secara relatif kelompok rumahtangga nelayan miskin untuk tipologi pesisir perdesaan memilik tingkat ketahanan pangan yang relatif lebih baik dibandingkan dengan tipologi pesisir perkotaan.

Seperti terlihat pada Tabel 8, rumah tangga nelayan miskin di pesisir perdesaan yang tergolong dalam kategori rawan pangan dan agak rawan pangan lebih banyak dibandingkan dengan di persisir perkotaan, yaitu masing-masing sebanyak $16,67 \%$ dan $80,56 \%$ untuk pesisir perdesaan dan sebanyak $52,78 \%$ dan $38,89 \%$ untuk pesisir perkotaan. Sementara mereka yang tergolong dalam kategori tahan pangan di pesisir perdesaan $(2,78 \%)$ lebih banyak dibandingkan dengan di pesisir perkotaan (8,33\%).

Kondisi tersebut mengindikasikan bahwa pada tipologi kemiskinan pesisir perdesaan, rumahtangga nelayan miskin memiliki kondisi ketahanan pangan relatif lebih baik dibanding di pesisir perkotaan. $\mathrm{Hal}$ ini tersebut disebabkan karena rumahtangga nelayan di pesisir perkotaan relatif lebih mengalami tekanan dalam ketersediaan pangan, lebih sulit dalam akses pangan dan memanfaatkan pangan. Sebaliknya untuk rumahtangga

Tabel 8. Tingkat Ketahanan Pangan Rumahtangga Nelayan Menurut Tipologi Kemiskinan di Pesisir Perkotaan dan Perdesaan, 2010

Table 8. Food Security Level at Fisher's Household by Type of Poor in Urban and Rural Area, 2010

\begin{tabular}{|c|c|c|c|c|c|}
\hline \multirow{3}{*}{$\begin{array}{c}\text { Peubah Terikat/ } \\
\text { Dependent } \\
\text { Variable }\end{array}$} & \multirow{3}{*}{$\begin{array}{l}\text { Kategori/ } \\
\text { Categories }\end{array}$} & \multirow{3}{*}{$\begin{array}{l}\text { Selang Skor/ } \\
\text { Score }\end{array}$} & \multicolumn{2}{|c|}{$\begin{array}{c}\text { Tipologi Kemiskinan/ } \\
\text { Type of Poor }\end{array}$} & \multirow{3}{*}{$\begin{array}{c}\text { Rata-rata } \\
\text { Gabungan/ } \\
\text { Average }\end{array}$} \\
\hline & & & $\begin{array}{c}\text { Perisir } \\
\text { Perkotaan/ } \\
\text { Coastal } \\
\text { Urban Area }\end{array}$ & $\begin{array}{c}\text { Pesisir } \\
\text { Perdesaan/ } \\
\text { Coastal Rural } \\
\text { Area }\end{array}$ & \\
\hline & & & \multicolumn{2}{|c|}{ Persentase (\%)/percentage } & \\
\hline \multirow{5}{*}{$\begin{array}{l}\text { Tingkat } \\
\text { Ketahanan } \\
\text { Pangan } \\
\text { Rumahtangga } \\
\text { Nelayan Miskin } \\
\left(\mathrm{Y}_{2}\right) / \text { Level of } \\
\text { Food Security } \\
\text { of Poor Fisher's } \\
\text { Household }\end{array}$} & $\begin{array}{l}\text { Rawan Pangan/ } \\
\text { Food Insecurity }\end{array}$ & $25,00-45,00$ & 52,78 & 16,67 & 34,72 \\
\hline & $\begin{array}{l}\text { Agak Rawan } \\
\text { Pangan / Mildly } \\
\text { Food Insecurity }\end{array}$ & $45,01-65,00$ & 38,89 & 80,56 & 59,72 \\
\hline & $\begin{array}{l}\text { Hampir Rawan } \\
\text { Pangan /Nearly } \\
\text { Insecurity }\end{array}$ & $65,01-85,00$ & 8,33 & 2,78 & 5,56 \\
\hline & $\begin{array}{l}\text { Agak Tahan } \\
\text { Pangan/Mildly } \\
\text { Food Security }\end{array}$ & $85,01-105,00$ & 0,00 & 0,00 & 0,00 \\
\hline & $\begin{array}{l}\text { Tahan Pangan/ } \\
\text { Food Security }\end{array}$ & $105,01-125,00$ & 0,00 & 0,00 & 0,00 \\
\hline \multicolumn{3}{|l|}{ Jumlah/total } & 100,00 & 100,00 & 100,00 \\
\hline \multicolumn{3}{|c|}{ Jumlah Sampel (n)/Number of Sample } & 36 & 36 & 72 \\
\hline
\end{tabular}

Sumber: Data Primer Hasil Wawancara (2010)/Source: Primary Data by Interviewing (2010) 
nelayan miskin di pesisir perdesaan, ketiga indikator ketahanan pangan tersebut relatif memadai di banding dengan di pesisir perkotaan, meskipun masih belum dapat dikatakan dalam kondisi yang baik karena sebagian besar $(80,56 \%)$ rumah tangga nelayan miskin di pesisir perdesaan memiliki tingkat ketahanan pangan yang agak rawan pangan, sedangkan di pesisir perkotaan hanya sebagian besar $(52,78 \%)$ memiliki tingkat ketahanan pangan yang agak rawan pangan.

\section{Hubungan antara Tingkat Kesejahteraan dan Tingkat Ketahanan Pangan}

Berdasarkan hasil pengujian hubungan antara peubah tingkat kesejahteraan (Y1) dan peubah tingkat ketahanan pangan

(Y2) rumahtangga nelayan miskin di pesisir perkotaan (Tabel 10) dan di pesisir perdesaan (Tabel 11) diketahui bahwa kedua peubah tersebut memiliki hubungan positif yang nyata pada $\alpha / 2=0,01$. Hubungan positif yang nyata tersebut tergolong kuat baik untuk tipologi kemiskinan di pesisir perkotaan $(r=$ $0,743)$ maupun perdesaan $(r=0,689)$. Namun secara relatif hubungan tersebut tampak lebih kuat untuk rumahtangga nelayan miskin di pesisir perkotaan dibandingkan dengan di pesisir perdesaan. Temuan ini mengindikasikan bahwa perubahan tingkat kesejahteraan akan lebih peka dalam hal hubungannya dengan ketahanan pangan untuk rumah tangga nelayan miskin tipologi pesisir perkotaan dibandingkan dengan perdesaan. Dengan perkataan lain, kontribusi rendahnya tingkat kesejahteraan terhadap terjadinya permasalahan dalam ketahanan pangan rumahtangga nelayan miskin yang rendah (kerawanan pangan) relatif lebih besar di pesisir perkotaan dibandingkan dengan di pesisir perdesaan.

Selanjutnya bila hubungan antara peubah tingkat kesejahteraan (Y1) dan peubah tingkat ketahanan pangan (Y2) tersebut diuji menurut dimensinya masingmasing dari kedua peubah tersebut, sebagaimana tertera pada Tabel 11 dan Tabel 12, diketahui bahwa dimensi pengetahuan (Y1.3) dari peubah kesejahteraan berhubungan positif dan nyata (pada taraf bervariasi antara $\alpha / 2=0,01$ dan $\alpha / 2=0,05)$ dengan ketiga dimensi dari ketahanan pangan, yaitu dimensi ketersediaan pangan (Y2.1), dimensi akses pangan (Y2.2) dan dimensi pemanfaatan pangan (Y2.3). Hal lain yang menarik dari temuan ini, bahwa dimensi ketersediaan pangan (Y2.1) dari peubah ketahanan pangan (Y2) tampaknya hanya berhubungan dengan dimensi pengetahuan (Y1.3) dari peubah kesejahteraan.

Tabel 9. Hasil Pengujian Hubungan antara Tingkat Kesejahteraan (Y1) dengan Tingkat Ketahanan Pangan (Y2) Rumahtangga Nelayan Miskin di Perkotaan dan Perdesaan, 2010

Table 9. Test Result of Relationship Between Welfare Level (Y1) and Food Security (Y2) Test in Poor Fishers Household in Urban and Rural Area, 2010

\begin{tabular}{cc}
\hline $\begin{array}{c}\text { Tipologi Kemiskinan/ } \\
\text { Type of Poor }\end{array}$ & $\begin{array}{c}\text { Koefisien Korelasi antara Y1 dan Y2/ } \\
\text { Correlation of Coeficient Between Y1 and Y2 }\end{array}$ \\
\hline Pesisir Perkotaan/Urban & $0,743^{* * *}$ \\
Pesisir Perdesaan/rural & $0,689 * * *$ \\
\hline
\end{tabular}

\section{Keterangan/Remark :}

$* * *$ nyata pada taraf $\alpha / 2=0,01$ (2-tailed)/significant at level $\alpha / 2=0,01$ (2-tailed)

** nyata pada taraf $\alpha / 2=0,05$ (2-tailed)/ significant at level $\alpha / 2=0,01$ (2-tailed)

* nyata pada taraf $\alpha / 2=0,10$ (2-tailed)/ significant at level $\alpha / 2=0,01$ (2-tailed) 
Sementara untuk kedua dimensi peubah kesejahteraan lainnya (dimensi kesehatan dan gizi (Y1.1), dan dimensi kekayaan materi (Y1.2)) hanya berhubungan dengan kurang dari tiga dimensi yang dimiliki ketahanan pangan rumahtangga nelayan miskin baik di pesisir perkotaan maupun perdesaan. Seperti untuk dimensi kesehatan gizi (Y1.1) dari peubah kesejahteraan baik pada tipologi persisir perkotaan maupun perdesaan berhubungan positif dan nyata dengan dimensi akses pangan (Y2.2) dan dimensi pemanfaatan pangan (Y2.3) dari peubah ketahanan pangan. Demikian pula dengan dimensi kekayaan materi (Y1.2) dari peubah kesejahteraan untuk tipologi perkotaan hanya berhubungan positif dan nyata dengan dimensi pemanfaatan pangan (Y2.3), dan untuk tipologi perdesaan berhubungan positif dan nyata dengan dimensi akses pangan (Y2.2) dan pemanfaatan pangan (Y2.3) dari peubah ketahanan pangan.

Tabel 10. Hasil Pengujian Hubungan antara Indikator-indikator Kesejahteraan dengan Ketahanan Pangan Rumah tangga Nelayan Miskin di Perkotaan, 2010

Table 10. Test Result of Relationship Between Indicators of Welfare's and Food Security's Variables of poor fishers in Urban Area, 2010

\begin{tabular}{lccc}
\hline \multirow{2}{*}{$\begin{array}{l}\text { Indikator/ } \\
\text { Indicators }\end{array}$} & \multicolumn{3}{c}{ Koefisien Korelasi/Correlation Coeficient } \\
\cline { 2 - 4 } & $\begin{array}{c}\text { Ketersediaan Pangan/ } \\
\text { Food Availability }\end{array}$ & $\begin{array}{c}\text { Akses Pangan/ } \\
\text { Food Access }\end{array}$ & $\begin{array}{c}\text { Pemanfaatan Pangan/ } \\
\text { Food Utility }\end{array}$ \\
\hline $\begin{array}{l}\text { Kesehatan dan Gizi/ } \\
\text { Health and Nutrition }\end{array}$ & 0,180 & 0,354 & $0,661^{* *}$ \\
$\begin{array}{l}\text { Kekayaan Materi/ } \\
\text { Materials Property }\end{array}$ & 0,170 & $0,687^{* *}$ & 0,231 \\
Pengetahuan/Knowledge & $0,478^{* *}$ & $0,340^{*}$ & $0,351^{*}$ \\
\hline
\end{tabular}

Keterangan/Remarks :

*** nyata pada taraf $\alpha / 2=0,01$ (2-tailed)/significant at level $\alpha / 2=0,01$ (2-tailed)

** nyata pada taraf $\alpha / 2=0,05$ (2-tailed)/significant at level $\alpha / 2=0,05$ (2-tailed)

$*$ nyata pada taraf $\alpha / 2=0,10$ (2-tailed)/significant at level $\alpha / 2=0,10$ (2-tailed)

Tabel 11. Hasil Pengujian Hubungan antara Dimensi-dimensi Kesejahteraan dengan Ketahanan Pangan Rumahtangga Nelayan Miskin Perdesaan, 2010

Table 11. Test Result of Relationship Between Indicators of Welfare's and Food Security's Variables of poor fisher in Rural area, 2010

\begin{tabular}{lccc}
\hline \multirow{1}{*}{$\begin{array}{c}\text { Indikator/ } \\
\text { Indicators }\end{array}$} & \multicolumn{2}{c}{ Koefisien Korelasi/Correlation Coefficient } \\
\cline { 2 - 4 } & $\begin{array}{c}\text { Ketersediaan Pangan/ } \\
\text { Food Availability }\end{array}$ & $\begin{array}{c}\text { Akses Pangan/ } \\
\text { Food access }\end{array}$ & $\begin{array}{c}\text { Pemanfaatan Pangan/ } \\
\text { Food Utility }\end{array}$ \\
\hline $\begin{array}{l}\text { Kesehatan dan Gizi/Health } \\
\text { and Nutrition } \\
\text { Kekayaan Materi/Material } \\
\text { Properties }\end{array}$ & 0,176 & $0,419^{* *}$ & $0,475^{* *}$ \\
\begin{tabular}{l} 
Pengetahuan/Knowledge \\
\hline
\end{tabular} & 0,182 & $0,685^{*}$ & $0,416^{* *}$ \\
\hline
\end{tabular}

\footnotetext{
Keterangan/Remarks :

*** nyata pada taraf $\alpha / 2=0,01$ (2-tailed)/ significant at level $\alpha / 2=0,01$ (2-tailed)

** nyata pada taraf $\alpha / 2=0,05$ (2-tailed)/ significant at level $\alpha / 2=0,05$ (2-tailed)

$*$ nyata pada taraf $\alpha / 2=0,10$ (2-tailed)/ significant at level $\alpha / 2=0,10$ (2-tailed)
} 
Temuan tersebut menunjukkan bahwa dimensi pengetahuan (Y1.3) rumahtangga nelayan miskin baik pada tipologi pesisir perkotaan maupun perdesaan memiliki peran yang sangat penting dalam mendukung kondisi tingkat ketahanan pangannya, terutama dengan dimensi ketersediaan pangan (Y2.1), sedangkan kedua dimensi lainnya dari peubah kesejahteraan (dimensi kesehatan dan gizi (Y1.1), dan dimensi kekayaan materi (Y1.2) berhubungan dengan peubah ketahanan pangan namun tidak selengkap (sedominan) seperti yang dimiliki dimensi pengetahuan (Y1.3) dari peubah kesejahteraan.

Selain itu ditemukan pula bahwa ketiga dimensi dari peubah kesejahteraan (dimensi kesehatan dan gizi (Y1.1), dimensi kekayaan materi (Y1.2) dan dimensi pengetahuan (Y1.3)) berhubungan positif yang nyata dengan dimensi akses pangan dari peubah ketahanan pangan baik pada rumahtangga nelayan miskin tipologi pesisir perkotaan maupun perdesaan. Hal ini menunjukkan bahwa peubah tingkat kesejahteraan (melalui ketiga dimensinya) memiliki peran yang sangat penting dalam meningkatkan akses pangan (Y2.2) rumahtangga nelayan miskin, dan lebih penting dibanding perannya dalam meingkatkan ketersediaan pangan (Y2.1) dan pemanfaatan pangan (Y2.3) rumahtangga nelayan tersebut. Temuan ini relevan dengan pernyataan yang disampaikan oleh Setiawan (2010) bahwa ketahanan pangan sesungguhnya lebih menunjukkan adanya akses setiap individu untuk memenuhi kebutuhan pangan setiap saat terkait dengan upaya meningkatkan kesejahteraannya (Setiawan, 2010). Selain itu didukung pula oleh hasil penelitian Siregar (2009b) untuk tingkat makro dengan beras sebagai komoditi pangan utamanya yang menunjukkan nadanya kaitan yang kuat antara peubah kesejahteraan (pendapatan) dengan akses pangan rumahtangga di Indonesia.

\section{KESIMPULAN DAN IMPLIKASI KEBIJAKAN}

\section{Kesimpulan}

Tingkat kesejahteraan memiliki hubungan yang positif dan nyata dengan tingkat ketahanan pangan rumahtangga nelayan miskin baik untuk kasus tipologi kemiskinan di pesisir perkotaan maupun perdesaan. Secara relatif hubungan tersebut lebih kuat untuk kondisi rumahtangga nelayan miskin tipologi pesisir perkotaan dibandingkan dengan perdesaan. Berdasarkan dimensi dari kesejahteraan dan ketahanan pangan: (1) dimensi pengetahuan memiliki peran yang sangat penting (dominan) dalam mendukung ketahanan pangan rumahtangga nelayan miskin baik pada tipologi pesisir perkotaan maupun perdesaan, terutama dengan dimensi ketersediaan pangan; (2) keseluruhan dimensi dari kesejahteraan (dimensi kesehatan dan gizi, dimensi kekayaan materi dan dimensi pengetahuan) memiliki peran yang sangat penting dalam meningkatkan akses pangan rumahtangga nelayan miskin, dibanding perannya dalam meingkatkan ketersediaan pangan dan pemanfaatan pangan rumahtangga nelayan tersebut.

\section{Implikasi Kebijakan}

Terdapat hubungan timbal balik antara tingkat kesejahteraan dengan ketahanan pangan sehingga upaya meningkatkan ketahanan pangan rumahtangga nelayan miskin harus dikaitkan dengan upaya meningkatkan kesejahteraannya. Di sisi lain bila kita menginginkan upaya peningkatan kesejahteraan harus dikaitkan dengan upaya meningkatkan ketahanan pangan rumahtangga nelayan tersebut. Kedua hubungan timbal balik ini memberikan signal kepada para pihak yang bertanggung jawab terhadap kedua permasalahan tersebut untuk tidak melihatnya sebagai sesuatu yang terpisah atau saling lepas. 
Upaya nyata pencegahan masalah pangan adalah dengan pengembangan sistem peringatan dini (early warning system) terhadap masalah kerawanan pangan, khususnya di daerah-daerah yang berpeluang tinggi mengalami masalah tersebut, terutama di "kantong-kantong" kemiskinan (kesejahteraan rendah dan sangat rendah). Sistem tersebut perlu dirancang sehingga juga melibatkan masyarakat secara relatif luas. Dengan adanya sistem ini, masalah kerawanan pangan khususnya pada rumahtangga nelayan miskin diharapkan dapat dicegah sehingga tidak sampai berkembang menjadi gizi buruk apalagi busung lapar.

Akses rumahtangga nelayan miskin terhadap pangan setidaknya sama pentingnya dengan ketersediaan dan pemanfaatan bahan pangan itu sendiri. Meskipun produksi beras dapat ditingkatkan secara nyata, namun tidak ada jaminan bahwa masyarakat nelayan miskin tersebut mampu mengakses bahan pangan tersebut secara memadai. Oleh karena itu, pemerintah harus memperhatikan salah satu komponen penting dari akses, yaitu jaringan distribusi bahan pangan. Kelancaran distribusi pangan bergantung pada kecukupan prasarana dan sarana transportasi yang diperlukan, pergudangan, serta pasar dalam arti market place. Dari komponen ini kiranya tidak sulit untuk memperkirakan bahwa daerah atau kawasan dengan prasarana dan sarana minim cenderung memiliki peluang (probability) terkena rawan pangan yang lebih besar dibandingkan kawasan dengan prasarana dan sarana yang memadai.

\section{DAFTAR PUSTAKA}

Aviliani, E. 2009. Ekonomi Bisa Enam Persen. Republika Ahad 25 Oktober 2009.

Bakhit, I. Nicole G.V.R., Hans H.M., Victoria W., Thomas W., 2001. Attacking The Roots of Poverty. Menggempur Akar-Akar Kemiskinan. Marburg Consult. Yakoma PGI. Page
BPS. 2006. Tingkat Kemiskinan di Indonesia. Berita resmi Statistik No. 47/X/1 September 2006. Jakarta.

Cahyat, A., Gonner, C., dan Haug, M. 2007. Mengkaji Kemiskinan dan Kesejahteraan Rumahtangga: Sebuah panduan dengan Contoh dari Kutai Barat, Indonesia. Center for International Foretry Research (CIFOR). Bogor.

Chang, K.L. Haddad, J. Ramakrisna and Riel, F. 1997. Identifying the Food Insecure. The Aplication on Mixed - Method Approaches in India. International Food Policy Reseacrh Institute. Washington, D.C.

Daryanto, A. dan Hafizrianda, Y. 2010. ModelModel Kuantitatif untuk Peencanaan Pembangunan Ekonomi Daerah: Konsep dan Aplikasi. IPB Press, Bogor.

Hasbullah, J. 2006. Social Capital. Menuju Keunggulan Budaya Manusia Indonesia. Penerbit. MR-United Press Jakarta.

International Food Policy Reaseach Institue. 1992. Nutrition and Developmen: A Global Assesment. International Food Policy Reaseach Institue, Wasington, D.C.

Lawang, R.M.Z. 2005. Kapital Sosial Dalam Perspektif Sosiologik. Suatu Pengantar. Fisip UI Press. Fakultas IImu Sosial dan Ilmu Politik, Universitas Indonesia.

Levin, J. and Fox, J.A. 2007. Elementary Statistics in Social Research. Seventh Edition, Longman, USA.

Maxwell, S. and T.R. Frankenberger. 1992. Household Food Security: Concepts, Indicators, Measurements, A Technical Review. International Fund for Agricultural Development/United Children's Fund. Rome.

Neuman, W. 2006. Social Research Methods: Qualitative and Quantitative Approaches. Pearson International Edition. USA.

Satria, A. 2009. Menyimak Nasib Nelayan, Republika Ahad 1 Nopember 2009, Dari Ekologi Politik Nelayan, Penerbit LKIS, Yogyakarta. 
Sen. A. 1984. Employment, Technology, and Development. Indian ed. Oxford University Press, New Delhi.

Setiawan, B. 2010. Konsep dan Analisis Isue Kemiskinan dan Ketahanan pangan Masyarakat Pesisir. Makalah dalam Pelatihan metodologi Riset. Balai Besar Riset Sosial Ekonomi Kelautan dan Perikanan, Jakarta. Hal 2-3

Sherraden, M. 2006. Aset Untuk Orang Miskin. Perspektif Baru Usaha Pengentasan Kemiskinan. PT Raja Grafindo Persada, Jakarta.

Siregar, H., Wahyuniarti, D., dan N.A. Achsani. 2009a. Dampak Pertumbuhan Ekonomi Terhadap Penurunan Jumlah Penduduk Miskin. Buku: Makro-Mikro Pembangunan: Kumpulan Makalah dan Esai. IPB Press, Bogor.
Siregar, H. 2009. Kerawanan Pangan dan Upaya Penanggulangannya. Buku: Makro-Mikro Pembangunan: Kumpulan Makalah dan Esai. IPB Press, Bogor.

Solahuddin, S. dan Fatika, Y.K. 2005. Membangun Indonesia. IPBPress. Bogor.

Suhardjo. 1994. Pengertian dan Kerangka Pikir Ketahanan Pangan Rumahtangga. PSKPG, LP. IPB. Bogor.

Yudhoyono, S.B. dan Harniati. 2004. Pengurangan Kemiskinan di Indonesia: Mengapa Tidak Cukup dengan Memacu Pertumbuhan Enomi. Brigten Press, Bogor. Hal 2 